\title{
ПРИЕМ ПЕРЕВОРАЧИВАНИЯ В ЭНЦИКЛОПЕДИИ ТВОРЧЕСТВА МИЛОРАДА ПАВИЧА
}

julija.dragojlovic@gmail.com

Филологический факультет

Белградский университет

\begin{abstract}
Аннотация: В данной работе представлено исследование способов реализации приема переворачивания в романах Милорада Павича. Проанализированы примеры применения этого художественного приема на уровне технического оформления книги, сюжето- и образостроения, а также интертекстуальных модификаций. Вследствие переворачивания ролей героев, сфер их бытия, а также изменения хронологии предпосылки и заключения, причины и следствия происходит нейтрализация противоположностей (в часности таких как «явь - сон», «добро - зло», «прошлое - будущее», «живой - дух», «охотник - добыча», «оригинал - плагиат», «автор - читатель»), создается эффект манипулирования истиной, разрушается «горизонт ожидания» читателя. Имплицитный Автор здесь предстает как текстуальная конструкция, в которой воплощается архетип трикстеpa, расшатывающего однозначное, переворачивающего устоявшееся и привычное, отражающего взаимосвязанность и изменчивость элементов бытия. Представленный материал вписывается в теоретико-семиотический дискурс о трикстерстве как определенной текстуальной стратегии.

Ключевые слова: прием переворачивания, Милорад Павич, романы, трикстерство
\end{abstract}

Прием переворачивания не является предметом, прошедшим верификацию категориальности до уровня отдельной словарной статьи в литературоведческих энциклопедических изданиях, но в энциклопедии творчества сербского постмодерниста Милорада Павича это понятие следует выделить и посвятить ему отдельную научную статью. Считая, что прием переворачивания является одним из наиболее применяемых Павичем трюков, с помощью которого в нарративной структуре его произведений проявляется игровой дискурс, предлагаем рассмотреть некоторые примеры художественной реализации этого приема на материале романов ${ }^{1}$ писателя. В связи с этим также отметим, что применение Павичем переворачивания в моделировании довольно-таки целостного художественного мира «Pavić’s productions» вписывается в теоретический контекст феномена трикстерства.

Интересно, что у сербского писателя этот прием реализуется прежде всего и в своем буквальном значении - как механическое

1 На данном этапе исследования мы сосредоточили внимание только на романах писателя, считая, что именно в этом жанре можно проследить особенности, характерные для всего его творчества (учитывая, в частности, и известную его склонность к автоинтертекстуальности). 
движение. Роман «Внутренняя сторона ветра» (1991) читается с двух сторон, и обусловлено такое чтение прежде всего техническим решением книги-перевертыша, две взаимооборотные части которой помещены под одной обложкой. Одна часть посвящена истории героя, происходящей на рубеже XII-XIII столетий, а во второй повествуется судьба героини, жившей в ХХ столетии. Их разделяет несколько эпох, и совсем логично напрашивается вопрос: что связывает героев, которые жили в разные времена и не подозревали о существовании друг друга? Части книги, кроме обложки, связывет древнегреческий миф, о котором напоминает подзаголовок «Роман о Геро и Леандре». Герои двусторонней книги носят эти имена наряду с другими: Радача - Милько - Ириней - Леандр, Геронея - Геро. Павич обыгрывает миф в духе постмодернизма - создавая интертекстуальную открытую структуру. Читатель может начать чтение с части «Геро» или же с части «Леандр». Концы этих частей, соединяющиеся посередине книги, открывают читательской фантазии возможность создания «третьей части» - интерпретации смертей героев, в которых, собственно говоря, и соединяются их судьбы. Но до этого, кроме мифа-ориентира, только техническое оформление книги, требующее механического движения переворачивания, является основной инструкцией для читателя.

Этот механический прием чтения-переворачивания был эпизочидески описан еще в «Хазарском словаре» (1984). В нем упоминается, что в один из экземпляров лексикона Даубмануса были вмонтированы песочные часы:

Клепсидра, вставленная в оправу книги, была невидимой, но в абсолютной тишине во время чтения можно было услышать, как сыплется песок. Когда песок пересыпался, книгу надо было перевернуть и продолжить чтение в обратном направлении, с того места и до начала, - и тогда открывалось тайное значение книги² (Павић, Хазарски речник, 2003: 28).

Читатель «Внутренней стороны ветра» должен перевернуть книгу хотя бы раз, чтобы разгадать тайну соединения в мифе двух судеб героев Павича - Геро и Леандра.

Так же следует читать и двусторонний «роман для детей и других читателей», состоящий из истории для девочек «Невидимое зеркало» и истории для мальчиков «Пестрый хлеб» (2003). ${ }^{3}$ Конец каждой из двух историй в этой книге отсылает читателя к другой истории, начинающейся с другой стороны обложки, что связывает их в единое целое. Качунчица, героиня рассказа для девочек, предлагает почитать историю «Пестрый хлеб», в которой живет герой-мальчик, владеющий частью тайны невидимого зеркала - ключом, который может его открыть. В свою очередь, мальчику Евгению некий друг из

2 Здесь и далее в тексте перевод с сербского наш.

3 Появление в творчестве Павича книги в таком жанре обусловлено тем, что в 2003 году у писателя родилась внучка, которой, собственно, этот роман и посвящается. 
XXIII столетия предлагает перескочить в соседний рассказ «Невидимое зеркало», чтобы проверить, подходит ли к нему ключ, который тот нашел вместе с сестрой Теодорой. В произведении подчеркивается необходимость прочтения обеих частей «романа для детей и других читателей», комплементарность которых и определяет интригу: их нужно составить, чтобы получить право расскрыть тайну.

Таким образом, техническое оформление романов «Внутренняя сторона ветра», «Невидимое зеркало и Пестрый хлеб» действительно «намекает», что читатель должен осуществить механическое движение переворачивания книги-диптиха хотя бы раз, чтобы разгадать в первом случае тайну соединения в неомифе двух судеб - Геронеи-Геро и Радачи-Леандра, а во втором - загадку ключа и зеркала.

Судьба самого читателя в абстрактной проекции может зависеть от такого движения, если он захочет ее поискать в предложенном к «художественному» справочнику для гадания «Последняя любовь в Константинополе» (1994), используя дополнение к картам Таро и их толкование из содержания в конце этого романа. Например, «Маг» - первая карта-ключ в большой колоде Таро. Если выпадет правильно, карта будет означать спасение, творческую силу, оригинальность, благоприятное для какой-то работы время; если же выпадет перевернутой, тогда наоборот - утрату сил, возможность быть обманутым, плохое начало (Pavić, Poslednja ljubav u Carigradu, 2002: 224). Bce peшает механическое движение переворачивания, положенное в основу игры случайного проявления значимого смысла.

Конечно же, неудивительно, что у Павича находим не только переворачивание книги (или карт как приложения к ней), но и переворачивание деталей, отношений, стереотипов, известных сюжетов, то есть различных смысловых структур. В этом отношении следует упомянуть о регрессе к архаичным слоям сознания, к которому прибегает искусство, что отчетливо представлено в исследованиях глубинных структур семиотических систем искусства, в частности в работах Сергея Эйзенштейна, Михаила Бахтина, Клода Леви-Стросса. Эти известные имена объединяет тот факт, что их носители проявляли большой научный интерес к двоичным семиотическим оппозициям («верх - низ», «царь - раб», «мужское - женское», «чет - нечет» итд.). Общая теория карнавала как инверсии двоичных противопоставлений, намеченная Бахтиным, находит опору в этнологических исследованиях, посвященных обрядам переворачивания социального положения, которые осуществляются через травестизм. Для современной этнологии травестизм (как и другие карнавальные обряды) является одним из случаев ритуальной нейтрализации семиотически значимых оппозиций. Основным выводом структурной антропологии как части семиотики, особенно отчетливо сформулированным Леви-Строссом, является то, что в ритуалах и мифах постоянно ищется равновесие полярных двоичных противополож- 
ностей. В богатых семиотическими идеями последних работах Эйзенштейна («Метод» и «Grundproblem»), появившихся еще до известных концепций Бахтина и Леви-Стросса, представлены примеры разбора литературных «перевертываний» / перевертышей» и переодеваний карнавального типа и других соотношений, основанных на наличии бинарных оппозиций. Вячеслав Иванов, автор «Очерков по истории семиотики в СССР», в главе «Перевертыш и карнавал» замечает, что в исследованиях Эйзенштейна очень четко демонстрируеся, как эта структурная схема перемены мест элементов разных оппозиций в равной мере верна для «сатирической сказки-небылицы» Свифта, «поэтической притчи в реалистическом рассказе» Толстого и даже для «натуралистического тенденциозного Мопассана, далекого от условно-метафорической стилистики» (Иванов). Эйзенштейн рассматривает «перевертывание», или же «перевертыш», как литературно-языковый прием, реализующийся в немалом количестве формальных разновидностей и образцов.

Идеи упомянутых ученых, занимающихся культурологическими вопросами, связанными с нейтрализацией противоположностей, коррелируют с суждениями о феномене трикстерства - в частности с представленными антропологом Полом Радиным, - а также используются для поткрепления выводов об отдельных аспектах этого феномена в более поздних работах других авторов. Разные исследователи отмечают, что функциональное и семантическое наполнение архетипа трикстера реализуется в игре смешивания противоположных действий: творить и разрушать, утверждать и отрицать, обманывать и быть жертвой обмана (в том числе собственного). Трикстерство - это особый стиль поведения, который базируется на провокации, маскировании, эпатажности, мистификации, розыгрыше, переворачивании привычной иерархии устойчивых отношений и связей, явлений и понятий. Однако все эти действия отнюдь не обозначены агрессивностью, а наоборот, сопровождаются рассудительностью и хитрой улыбкой. Именно поэтому ирония как демонстрация неоднозначности - основной инструмент трикстера (Радин 1999: 98-99). Многозначность - а в большой степени и неопределенность - позиции и цели трикстера в собственной игре и отсутствие единых устоявшихся правил этой игры коррелируют с запросами культурной парадигмы постмодернизма. Искусство актуализирует культурный архетип трикстера, как правило, на критических этапах общественной истории, при переходе одной эпохи к другой. По мнению исследователей, он очень ярко прослеживается в литературных практиках авангардистского и постмодернистского письма (Гончар 2004; Семків 2004). В мифологии и литературе этот архетип реализуется прежде всего в образе героя, ${ }^{4}$ имеющего уникальную функциональную и семантичес-

4 Галерея таких трикстеров большая и постоянно пополняется: Протей и Гермес у греков, Вакдъюнкага у американских индейцев Виннебаго, Эдшу у западноафриканских племен, Локи в скандинавской мифологии, Одиссей в эпосе Гомера, Хануман в 
кую наполненность: он - безликая многоликость, которая с легкостью самопревращается, балансируя между противоположностями, играя своими масками и разрушая однозначность и статичность смысла, а следовательно, и истины, превращая все в объект игры (Радин 1999: 257). Архетипная природа трикстера позволяет не только выявлять его в мифах и в искусстве как героя в разных ипостасях, но и говорить о феномене трикстерства как о наборе стилеобразующих функций, применяемых в конструировании художественного текста. Исходя из этого, исследователи при анализе «авторского поведения» в произведениях некоторых писателей определяют его как трикстерское и, соответственно, на основании определенных элементов поэтики выводят образ автора-трикстера - как абстрактную категорию адресанта специфической художественной информации, которую воспринимает реципиент (Гончар 2004; Семків 2004).

Если рассматривать все литературное творчество Павича как целостную макрокоммуникативную интеракцию, ${ }^{5}$ в нем обнаруживается некоторый интегральный образ Автора, творческое поведение которого можно трактовать как трикстерское. Осуществленный нами ранее анализ средств текстообразования и нарративной структуры романов этого писателя ${ }^{6}$ позволяет говорить, что рецепция произведений Павича - особенно критическая рецепция - актуализирует архетип трикстера в качествеимплицитного Автора ${ }^{7}$ этихпроизведений.

Как отмечает Инна Гончар, в основе трикстерского «игрового действа» лежат приемы маскирования, мистификации и переворачивания. В нашей работе поставлена цель подробнее представить примеры применения приема переворачивания в романах Павича, в частности литературные инверсии на уровне сюжето- и образостроения.

«Рамаяне», Ходжа Насреддин из «Тысячи и одной ночи», шакал Пингалака из «Панчатантры», Панчинелло в итальянской комедии, Рейнеке-лис у Гете, Феликс Круль у Томаса Манна и. т. д. - См.: Радин 2004.

5 Такой ракурс считается возможным ввиду повторяемости в различных произведениях концептуальных и стилевых характеристик, образующих неповторимый идиолект сербского писателя, вследствие чего его литературная практика воспринимается как цельнооформленная художественно-эстетическая реальность.

6 См.: Білоног 2005; Білоног 2006.

7 Имплицитний Автор рассматривается нарратологами как «гипотетическое Я писателя внутри текста, не касающееся его эмпирического Я», как «абстрактный конструкт реципиента», постулируемый необходимостью существования адресанта художественной информации в процессе осуществления литературной коммуникации (Ильин 2000: 98-99). По мнению Умберто Эко, имплицитний Автор, которого рисует воображение читателя, есть ничто иное как текстуальная стратегия, так называемый «антропоморфный» принцип, организующий все средства повествования и рассказчика включительно (Еко 2004: 32-34). Таким образом, понятие имплицитного Автора коррелирует с такими категориями, как стиль писателя и поэтика произведения. Для удобства оперирования термином «имплицитний автор», который как инстанция абстрактного коммуникативного уровня является категорией высшего порядка (по отношению к эксплицитному, фиктивному автору-нарратору), мы используем написание с большой буквы - Автор, - тем самым подчеркивая абстрактность и превосходство этой инстанции. 
Одним из способов применения писателем приема переворачивания является изменение хронологии предпосылки и заключения, причины и следствия. Время, по мнению Павича, не должно всегда течь от причины к последствию. В «Хазарском словаре», например, родители умирают смертью (точнее смертями) своих детей: «Смерть - это единственное, что наследуется в обратном порядке, против течения времени, переходит от младших к старшим, от сына к отцу; смерть предки наследуют от потомков, будто какой-то дворянский титул» (Павић, Хазарски речник, 2003: 255). Именно так произошло с известным героем лексикона Аврамом Бранковичем. Роман «Звездная мантия» (2000) с подзаголовком «астрологический путеводитель для непосвященных» Павич наградил эпиграфом «Познайте свое прошлое вовремя, потому что и у него заканчивается срок годности...» Авторство этого эпиграфа Павич приписал Архондуле Нехаме, одной из героинь, появляющейся в главах этой книги, посвященных зодиакальным знакам Девы и Близнецов. Во втором фрагменте она переживает прозрение: «будущее тела человека - это только прошлое его души» (Pavić 2001: 166). Идея афоризма основана на переворачивании взаимосвязей в абстрактных направлениях «прошлое - будущее» и «тело - душа», где компоненты последней оппозиции меняются местами. В то время как с помощью знаков зодиака принято узнавать о своем будущем, Милорад Павич те же зодиакальные знаки, являющиеся названиями глав этой книги, ставит на службу познания прошлого. Кроме того, что роман «Звездная мантия» представляет собой своеобразный «прогноз на прошлое», в нем есть еще одно интересное «наоборот»: в главе «Овен» содерждится «Пистик» (как замечено в тексте, это слово «в старославянском означает настоящий, достоверный»): «Вместо того, чтобы, как сонник, на основе снов предсказывать явь, пистик, исходя из яви предсказывает, что вам приснится во сне» (Pavić 2001: 78-79). Таким образом, в отличие от традиционного сонника, здесь сам сон является следствием событий реальной жизни. Соответственно, читателю приходится бродить лабиринтами яви и сна, иногда теряясь в них, то есть путая друг с другом.

Образцом «нарративного оборотня» является и рассказ «Кресло для умирания» в романе-антологии «Бумажный театр». События здесь разворачиваются двовекторно, «туда и обратно» (сначала в направлении к прошлому, а затем - к будущему), поэтому они являются «переменными величинами»: в зависимости от вектора движения нарратива, в кресле, вокруг которого он концентрируется, умирают разные герои. Причем точкой пересечения этих векторов является краткий диалог-конфликт между эксплицитными автором и читателем, выступающими в тексте персонажами:

ЧИТАТЕЛЬ: Этот тип вообще сошел с ума! Забыл, что написал и сейчас повторяется! - ПИСАТЕЛЬ: Молчи уже! Каждую вещь, чтобы ее услышали, надо сказать по крайней мере дважды. В конце концов, ты забываешь, 
что я, как ни крути, умнее тебя. - ЧИТАТЕЛЬ: ? - ПИСАТЕЛЬ Всегда тот, кто знает конец, умнее того, кто не знает! Я знаю конец этого рассказа, а ты его еще не знаешь! Поэтому успокойся, приятель, и молчи, пока не прочитаешь написанного! (Павић 2007: 224).

Очевидно, что включение этого метатекстуального фрагмента в повествование ставит под прицел иронии вопрос авторско-читательского равноправия.

Переворачивание ролей, которые герои исполняют в романе, означает трансформацию функциональной нагрузки персонажей, что происходит под риском превращения их в свою противоположность. На таком переворачивании позиций построен фрагмент-парабола о Плакиде из «романа для любителей кроссвордов» «Пейзаж, нарисованный чаем» (1988): зверь-призрак - на самом деле комбинация зверя, птицы, рыбы и черта, - за которым гонится охотник Плакида, превращается в своего преследователя, то есть в Плакиду; а сам Плакида становится добычей собственной добычи, необычного гротескно-демонического зверя (Pavić, Predeo slikan čajem, 2002: 393-396). Преследуемый и преследователь меняются ролями. Похожее переворачивание происходит между Афанасием Разиным и чертом Азередо, когда в сюжетном комбинировании фрагментарного художественного повествования романа оказывается, что черт должен выполнить миссию спасителя, стать на пути Разину, деятельность которого якобы угрожает уничтожением всему человечеству, а следовательно, представляет угрозу и для демонов, ибо «только через человека они еще имеют связь со своей безгрешной молодостью, с самими собой до падения в грех и, собственно, с Богом (Pavić, Predeo slikan čajem, 2002: 365). Такое переворачивание демонстрирует распространенное в литературе отрицание абстрактной границы между добром и злом.

Интересным проявлением трикстерства является переворачивание зеркально полярных сфер бытия героев. Речь идет о корреляции сна и яви в мире художественной фикции Павича, заключающейся в одновременном бытии-пребывании героя в собственной действительности и в чьем-то сне, который, в свою очередь, для кого-то другого имеет координаты реального мира. Так, Аврам Бранкович и Самуэль Коэн предстают в «Хазарском словаре» как зеркальные двойники: сон одного является явью другого и наоборот. Переворачивание этих сфер бытия дает потрясающие возможности для развития сюжета в направлении, которое не совпадает с ожиданиями читателя, за счет чего создается эффект ускользания истины. Героиня одного из фрагментов романа «Семь смертных грехов» (2002), старательно записывая житие прихожанки Даласены, неожиданно не только для себя, но и для читателя, - обнаруживает, что ее жизнь является только продуктом сна прихожанки; следовательно, ее повествование осуществляется из перспективы чужого сна. «Поверь, 
и ты мне снишься каждый вечер. Вот, именно сейчас, когда мы говорим и ты записываешь, - все это в моем сне», - говорит Даласена

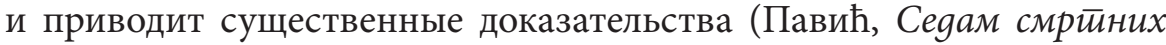
iрехова, 2005: 62). Аналогичное переворачивание наблюдаем в «Уникальном романе» (2004), только здесь этот прием уже реализуется в синхронном сочетании прошлого и будущего путем вызывания духов. Герои, которым удалось вызвать Виктора, одного из обитателей «потустороннего мира», выясняют, что его мир реальнее от их мира, который оказывается миром мертвых. «Это не вы меня вызвали, а я - вас. Вы - духи, а не я», - говорит Виктор и также выдвигает свои доказательства (Павић 2004: 133). В романе «Другое тело» (2006) выясняется, что болезнь Лизы Свифт во сне означает болезнь ее мужа наяву. А когда к нему в сон приходит демонической природы триносая девочка Бафомет, она его уверяет, что это он ей снится, а не наоборот. Итак, сон и реальность как параллельные бытийные сферы отражают друг друга и, как правило, сосуществуют как потусторонняя и «поэтусторонняя» жизни.

Один из интересных случаев формального переворачивания у Павича представлен также в «Уникальном романе», важным дополнением к которому является «Синяя тетрадь. Каталог всех ста концовок "Уникального романа"». Эти две книги могли бы тоже быть технически оформлены в книгу-перевертыш, как «Внутренняя сторона ветра» и «Невидимое зеркало и Пестрый хлеб», поскольку соприкасаемы по принципу взаимодополнения. Мирьяна Боянич Чиркович указывает на то, что Павич устанавливает между этими двумя текстами связь, как между оригиналом и антиципированным плагиатом, тем самым иронично «отвечая» некоторым критикам на обвинения в его неоригинальности (Бојанић Ћирковић 2015: 558-559). За основу такого суждения она берет во внимание запись из фрагмента 73 «Синей тетради», в которой следователь Евгений Стросс сообщает, что увидел в одной витрине книгу «Уникат» с соответствующей рекламой на обложке - информацией о том, что это новый роман автора «Хазарского словаря». Следователь удивляется: «Неужели кто-то уже написал роман о случае госпожи Лемпицкой и ее любовника Моритца Эрлангена до того, как я успел решить этот случай?» (Павић, Плава свеска, 2005: 87). С точки зрения хронологии, по мнению Мирьяны Боянич Чиркович, «Синяя тетрадь» представлена как плагиат «Уникального романа», но антиципированный плагиат, поскольку здесь явны следующие критерии этого явления, обозначенные Пьером Байяром: схожесть, отсутствие намерения плагиаторства, временная инверсия и диссонанс, то есть впечатление, что плагиаторские фрагменты не идентичны с текстом оригинала. «Синяя тетрадь» как своебразный дневник следователя Стросса, в котором заложена тен-

8 Позволим заметить, что самоповторения у Павича трактовать можно как неоригинальность или же как интересный пример автоинтертекстуальности. 
денция перерастания в роман о случае «Лемпицкая \& Со» и в котором эпистолярное повествование ведется от первого лица, выделяется по сравнению с доминантной нарративной техникой от третьего лица, но в то же время каждый его фрагмент является одной из ста концовок, помещенных в эпилог «Уникального романа», и тем самым составляет формальную уникальность этого романа (Бојанић Ћирковић 2015: 559). В дополнение надо отметить, что в эпилоге (точное название этого раздела «Уникального романа» - «Эпилог, или “Синяя тетрадь” ) автором завершающего фрагмента (каждого из ста вариантов) назван покойный (!) следователь Евгений Стросс. Этот факт является поводом задуматься, не представляется ли текст «Уникального романа» как антиципированный плагиат по отношению к «Синей тетради». Следственные связи можно перевернуть, а вывод логичен и в таком, и в обратном порядке. Не к этому ли стремился Павич, играя с темой плагиата, которая, к тому же, вписывается в любимую им проблему (или же игру) относительно релятивизации авторства?

Исследование реализации приема переворачивания в творчестве сербского посмодерниста совершенно логично нас приводит к вопросу о литературной коммуникации, в которой автор и читатель являются элементами бинарной оппозиции. Бранислав Яковлевич отмечает, что Павич «построил свою карьеру» прежде всего на идеях нелинейности литературы и интерактивности - привлечения реципиента к сотворчеству (Jakovljević 2007). Действительно, металитературные алгоритмы его романов направлены на пропаганду новой, игровой интерактивной практики чтения, которой способствует (и даже ее провоцирует) нелинейная практика письма. Провокация начинается уже с жанровых определений. Каждое из них - роман-словарь, роман-таро, роман-антология и т. д. - представляет соответствующую модель, которая делает возможным выбор читателем собственной траектории рецепции. Чтобы «привести в движение» такую модель, то есть сделать ее функциональной, писатель как на паратекстуальном уровне, так и на собственно текстуальном, привлекает читателя к игре в текстотворение.

Нарративно-рецептивная стратегия Павича имеет целью разворачивание игровой авторско-читательской коммуникации. Сербский писатель на эксплицитном коммуникативном уровне вводит самоироничного первичного нарратора в масках «лексикографа», «издателя», «редактора», «составителя», «писателя». Каждая из них, вопервых, удерживает фрагментарную, гетерогенную, полифоническую структуру произведения как нарративную целостность; во-вторых, в той или иной степени способствует дискредитации авторской позиции, распространенной в постмодернистской теории и практике, в частности из-за известного концепта Ролана Барта «смерть автора», демонстрирующего мнение, что литературный текст является результатом работы не автора-демиурга, а автора-скриптора, которому суждено только переписывать и компилировать существующие дости- 
жения искусства слова. Главная же функция, которую выполняет этот «издатель», «редактор», «лексикограф» и т. д., заключается в создании необходимой литературной коммуникативной ситуации, где эксплицитный читатель (а соответственно, и имплицитний адресат художественной информации) декларативно наделяется творческой активностью в акте рецепции произведения. Десакрализуя авторское начало и активизируя персонажного адресата, Павич опять-таки именно переворачивает эти две нарративные категории - автора и читателя.

С другой стороны, это переворачивание у Павича не так однозначно. Самоироничное примеривание субъектом творчества авторских масок (довольно близких по своей подчеркнуто неавторитарной сущности) не умаляет возможности реципиента почувствовать и себя объектом иронии со стороны того, кто стоит за масками, - имплицитного Автора, воображаемого адресанта художественной информации. На абстрактном коммуникативном уровне под прицелом иронии оказывается читательская наивность, поскольку провозглашаемая свобода реципиента в процессе сотворчества, как правило, ограничивается выбором последовательности чтения соответствующих разделов. ${ }^{9}$ Имидж имплицитного Автора, «вчитываемый» в сознание реципиента, оказывается изменчивым, неоднозначным, трикстерским. В его «текстуальном» поведении наблюдаются нередкие попытки перевернуть - видоизменить, трансформировать, переиграть - какое-то значение А так, чтобы разрушить «горизонт ожидания», то есть выявить еще значение Б, противоречивое по отношению к А, но тождественное с ним в потенциальной возможности быть истинным. Такое переворачивание имеет целью не утверждение одного из значений, а выявление амбивалентного существования этих значений, даже если они противоположны. Каждое из них является истинным в течение того времени, когда реципиент их такими воспринимает. «Нет ничего такого на белом свете, что однажды не могло бы стать истиной, как и остановившиеся часы, ведь в какой-то момент они показывают точное время», - утверждает рассказчик из «Пейзажа, нарисованного чаем» (Pavić, Predeo slikan čajem, 2002: 222). Уже в лексиконе один из героев заметил, что «истина - это только трюк» (Павић, Хазарски речник, 2003: 221). Это лаконичное и меткое выражение можно назвать одной из ключевых формул постмодернистской эстетики с ее «эпистемологической неуверенностью». На имплицитном уровне художественный авторско-читательский диалог в мире «Pavićs productions» разворачивается в игре, в основе которой - установка на переосмысление, переворот, десакрализацию общепринятых понятий. Вышеуказанные примеры использования Павичем приема переворачивания демонстрируют тяготение к нейтрализации семиотически значимых оппозиций, характерное для ритуалов и мифов, которыми так часто питается искусство.

9 Используя нарративную модель Вольфа Шмида, ранее мы уже анализировали особенности авторско-читательской коммуникации в творчестве Павича. См.: Білоног 2008. 
У Павича также можно найти примеры использования этого художественного приема на уровне интертекстуальных связей, проявляющихся в диалоге общекультурных компетенций автора и читателя. Реинтерпретация некоторых известных сюжетов, которую осуществляет Павич, строится именно на переворачивании. Например, трудно не заметить мифологическую основу романа «Последняя любовь в Константинополе». В нарративе этого текста проступают известные древнегреческие мифы, архетипическая природа которых подвергается очередной, травестированной реинтерпретации. Так, миф об Эдипе и параллельно с ним - как его отражение - миф об Электре варьируются в теме сложных отношений между родителями и сыновьями и дочерьми в семьях Опуичей, Калоперовичей и Тенецких. Миф об Эдипе и Иокасте прочитывается как «перевернутый» в эпизоде об Арсении Калоперовиче и его матери Растине: в отличие от древнегреческого прототипа, Арсений хочет убить своего настоящего отца Харлампия Опуича, но не делает этого. Как отмечает Алла Татаренко, Павич нередко тематизирует эти мифы не в первоначальном контексте, а как праоснову известных комплексов - комплекса Эдипа и комплекса Электры (собственно «женского эдипового комплекса»), - которым определяют бессознательное влечение ребенка к родителю противоположного пола и агрессивное чувство к родителю своего пола. Это является проявлением авторской иронии, которой констатируется факт, что для большей части современных читателей интертекстуально активизированные мифы об Эдипе или Электре ассоциируются прежде всего со специфическим психическим отклонением (Татаренко 2010: 408).

Наименее исследованный текст писателя «Невидимое зеркало и Пестрый хлеб» также обращает на себя внимание, когда речь идет об интертекстуальной игре с ассоциативными возможностями читательского опыта. Несмотря на авторскую дефиницию - «роман для детей и других», - которая отрицает ограничение читательского возраста и опыта, необходимых для рецепции этого текста, можно ожидать, что на уровне интертекстуальной коммуникации он будет отсылать к кодам так называемой детской литературы. Такое ожидание вполне «удовлетворяется», в частности в «истории для девочек» под названием «Невидимое зеркало». Эта часть является своеобразным эпистолярным путеводителем по разным странам и городам, к которому, помимо ярких иллюстраций, входит содержание десяти открыток, которые некая Роза-бегунья, путешествуя по миру в поисках «невидимого зеркала», посылает своей подруге, девочке Качунчице; открытки - это страницы с картинками, комментариями и интересными историями, происходящими с ней. Персонифицированная Роза, бесспорно, вызывает ассоциации с одной из самых популярных авторских «сказок для взрослых и детей» - с «Маленьким Принцем» Антуана де Сент-Экзюпери. У французского писателя Роза красивая и капризная, в то время как 
у Павича она приобретает черты путешественника-авантюриста, которым являлся романтический Маленький Принц. Таким образом, сербский автор создает «перевернутую» ситуацию. Подобные интертекстуальные переворачивания придают игре в отыскивание связей с прототекстами большей сложности, но и доставляют большее удовольствие читателю от замеченного им авторского трюка.

Таким образом, творчество Павича еще раз подтверждает, что художественный прием переворачивания универсален, как его, в частности, характеризовал и Энзенштейн. Он имеет трикстерскую архетипную природу и обеспечивает репрезентацию неоднозначности всех вещей в мире, многоплановости и относительности человеческих ценностей, раздробленности явлений на противоположности. У Павича этот прием реализуется на уровне технического оформления книг, сюжето- и образостроения, а также интертекстуальных модификаций. Части его романов-перевертышей соединены по принципу взаимодополнения и только как диптих открывают читателю новые смысловые связи, не артикулированные по отдельности. Вследствие переворачивания ролей героев, сфер их бытия, а также изменения хронологии предпосылки и заключения, причины и следствия происходит нейтрализация противоположностей (в часности таких как «явь - сон», «добро - зло», «прошлое - будущее», «живой - дух», «охотник - добыча», «оригинал - плагиат», «автор - читатель»), создается эффект манипулирования истиной, разрушается «горизонт ожидания» читателя, что подчеркивает амбивалентность создаваемого мира в творчестве Павича. Соответственно, имплицитный Автор здесь предстает как текстуальная конструкция, в которой воплощается архетип трикстера, расшатывающего однозначное, переворачивающего устоявшееся и привычное, отражающего взаимосвязанность и изменчивость элементов бытия. Вместе с тем, на интертекстуальном уровне усложняет, но одновременно и обогащает авторско-читательскую коммуникацию игра в узнавание и декодирование инверсионных модификаций элементов прототекста. Нарративно-рецептивная стратегия Павича, в которой применяется художественный прием переворачивания, нацелена на создание новой читательской идентичности: желаемый (имплицитный) читатель - это игрок-исследователь, креативность воображения которого сочетается с критическим восприятием текста. Эффективность литературной коммуникации определяется его игровым настроением и интерпретационной общекультурной компетентностью. 


\section{ИЗВОРИ}

Павић, Милорад. Невияливо оілеgало. Шарени хлеб. Београд: Дерета, 2003.

Павић, Милорад. Плава свеска: катиалої свих сйо завриейака романа-gелиее Уникат. Београд: Дерета, 2005.

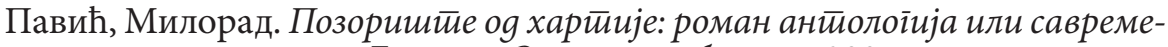
на светиска йрича. Београд: Завод за уџбенике, 2007.

Павић, Милорад. Сеgам смритних ірехова. Београд: Дерета, 2005.

Павић, Милорад. Уникай: роман-gелйа. Београд: Дерета, 2004.

Павић, Милорад. Хазарски речник: роман-лексикон у 100.000 речи. Београд: Дерета, 2003.

Pavić, Milorad. Drugo telo. Beograd: Dereta, 2006.

Pavić, Milorad. Zvezdani plašt: astrološki vodič za neupućene. Beograd: Dereta, 2001.

Pavić, Milorad. Poslednja ljubav u Carigradu: priručnik za gatanje. Beograd: Dereta, 2002.

Pavić, Milorad. Predeo slikan čajem. Beograd: Dereta, 2002.

Pavić, Milorad. Unutrašnja strana vetra ili Roman o Heri i Leandru. Beograd: Dereta, 2002.

\section{ЛИТЕРАТУРА}

Білоног, Юлія. „Авторство як об’єкт іронії у романах М. Павича”. Вісник Київського начіонального університету імені Тараса Шевченка 2 (2006): 9-12.

Білоног, Юлія. „Інтерактивність у авторсько-читацькій комунікації «по-павичівськи» (на матеріалі романної творчості М. Павича)". Компаративні дослідження слов'янських мов і літератур. Ювілейний випуск (до 120-річчя 3 дня народження Л. Булаховського). (2008): 274-281.

Білоног, Юлія. „Трикстеріада імпліцитного Автора в наративі Павичевих романів". Літературознавчі студіï 14 (2005): 51-55.

Бојанић Ћирковић, Мирјана. „Домети читалачке слободе у Павићевој поетици на примеру романа Уникат̈". Наука и слобоgа : зборник раgова са Научної скуйа (Пале, 6-8. јуни 2014.). Ур. Милош Ковачевић. Источно Сарајево: Филозофски факултет, 2015. 547-562.

Гончар, Інна. „Трикстерське співвідношення “я” та “іншого” в контексті авангардизму”. Літературознавчі стуgіï 10 (2004): 65-69.

Еко, Умберто. Роль читача. Дослідження з семіотики тексииів. Пер. 3 англ. Мар'яни Гірняк. Львів: Літопис, 2004.

Иванов, Вячеслав. Очерки по истории семиотики в СССР. Москва: Наука, 1976. <http://philologos.narod.ru/semiotics/ivanov_gl2.htm> 27.04.2020. 
Ильин, Илья. Постмодернизм: Словарь терминов. Москва: ИНИОН PAH - Intrada, 2000.

Радин, Пол. Трикстер. Исследование мифов североамериканских индейиев с комментариями К.Г. Юнїа и К.К. Кереньи. Пер. с англ. В.В. Кирющенко. Санкт-Петербург: Евразия, 1999.

Семків, Ростислав. Іронічна структура: типи іронії в художній літераmурі. Київ: Видавничий дім «КМ Академія», 2004.

Татаренко, Алла. „Роман М. Павича «Остання любов у Царгороді»: проблеми інтертекстуальності та семантизації форми”. Компаративні дослідження слов'янських мов і літератур 11 (2010): 402-414.

Jakovljević, Branislav. „Država kao sprava”. Beton br.12, 6.02. 2007. <https:// www.elektrobeton.net/mikser/drzava-kao-sprava/> 14.03.2020.

Јулија Драгојловић

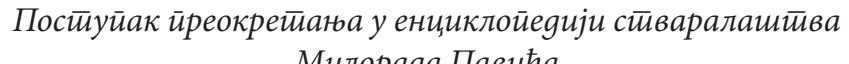

Милораgа Павића

\section{Резиме}

У раду се истражују начини реализације поступка преокретања у Павићевим романима, с обзиром на његову архетипску природу што се уклапа у теоријско-семиотички дискурс о трикстерству као одређеној текстуалној стратегији. Код Милорада Павића се овај поступак примењује на нивоу техничког обликовања књига, креирања ликова и сижеа, као и интертекстуалних модификација. Међу романима овог писца има таквих који су састављени од два дела штампана у међусобно обрнутим смеровима, ти делови су повезани по принципу комплементарности и само као диптих откривају читаоцу нове семантичке везе које нису артикулисане у случају одвојености текстова. Због преокретања улога јунака, сфера њиховог битисања, као и промене хронологије претпоставке и закључка, узрока и последице, долази до неутрализације супротности („стварност - сан“, „добро - зло“, „прошлост - будућност“, „живо биће - дух“, „ловац - плен“, „оригинал - плагијат“, „аутор - читалац“), ствара се ефекат манипулације истином, руши се „хоризонт очекивања“ читаоца, чиме се наглашава амбивалентност креираног света у Павићевом стваралаштву. Сходно томе, овде имплицитни Аутор као текстуална конструкција активира архетип трикстера који изокреће све познато и устаљено, приказује међусобну повезаност и променљивост супротности, релативизује људске вредности. На интертекстуалном нивоу, игра препознавања и декодирања инверзивних модификација елемената прототекста компликује, али истовремено и обогаћује ауторско-читалачку комуникацију. Павићева наративно-рецептивна стратегија у којој је релевантан поступак преокретања, има за циљ стварање новог идентитета читаоца: жељени (имплицитни) читалац је истраживач-играч чија се машта и општекултурне компетенције комбинују са критичком рецепцијом текста.

Кључне речи: поступак преокретања, Милорад Павић, романи, трикстерство

Примљен: 19. 5. 2020.

Прихваћен: 25. 5. 2021. 